\title{
Combination of Bawang Dayak Extract and Acarbose against Male White Rat Glucose Levels
}

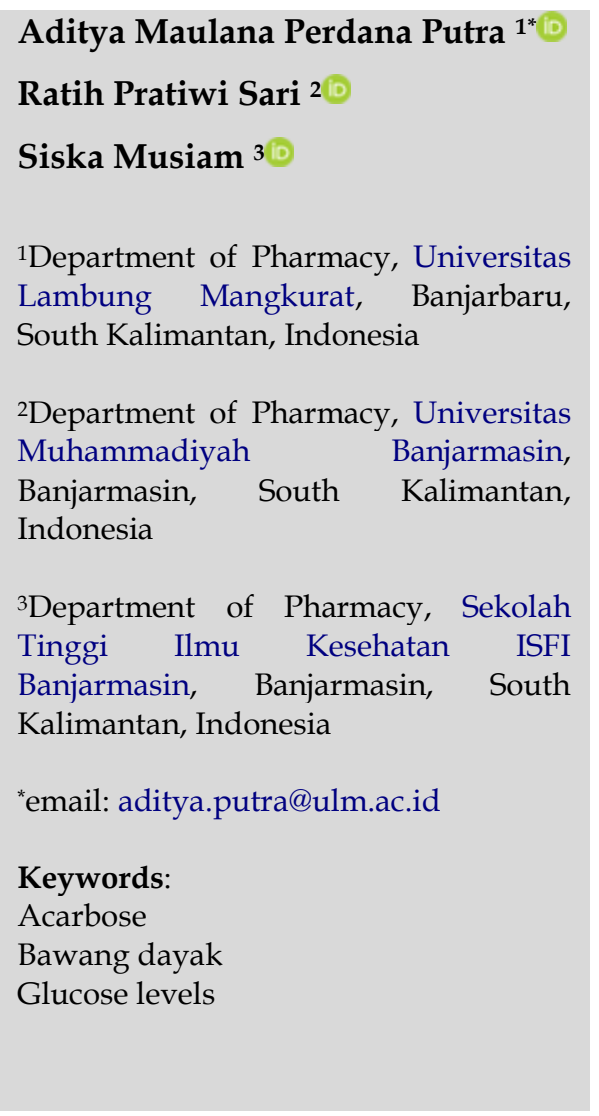

\begin{abstract}
Diabetes is a chronic metabolic disease with signs of increased blood glucose levels. Type 2 diabetes is common diabetes in adults. Bawang dayak is one of the plants believed to have the efficacy of curing various types of diseases. The purpose of this study was to find out the comparison of hypoglycemic effects between combinations of bawang dayak extract and acarbose with single acarbose. This study was an experimental study using 32 white mice divided into two groups. Group one was given a combination of bawang dayak at a dose of $100 \mathrm{mg} / \mathrm{kg} \mathrm{BW}$ and acarbose at a dose of $40 \mathrm{mg} / 100 \mathrm{~g} \mathrm{BW}$, while group two was given acarbose at a dose of $40 \mathrm{mg} / 100 \mathrm{~g}$ BW. Treatment is administered after the test animal is induced with dexamethasone at a $1 \mathrm{mg} / \mathrm{kg}$ BW dose dissolved in $\mathrm{NaCl} 0.9 \%$ subcutaneously for 12 days. Measurement of glucose levels was carried out using a glucometer. Data retrieval was carried out every three days for 15 days after previously fulfilled for +10 hours. Blood glucose level data were analyzed with the General Linear Model test. The combination of bawang dayak-acarbose onion extract had a greater decrease in blood glucose levels than single acarbose. Average reduction in blood glucose levels for $\mathrm{D}+3 ; \mathrm{D}+6$; $\mathrm{D}+9$; $\mathrm{D}+12$; and $\mathrm{D}+15$ was 187.31; 168.56; 140.81; 119.81; and $102.56 \mathrm{mg} / \mathrm{dl}$, respectively. The General Linear Model test results showed a $\mathrm{p}<0.05$ value that significantly impacted blood glucose levels between groups.
\end{abstract}

Received: September 30th, 2020

Accepted: April 1st, 2021

Published: May 30th, 2021

C 2021 Aditya Maulana Perdana Putra, Ratih Pratiwi Sari, Siska Musiam. Published by Institute for Research and Community Services Universitas Muhammadiyah Palangkaraya. This is an Open Access article under the CC-BYSA License (http://creativecommons.org/licenses/by-sa/4.0/). DOI: https://doi.org/10.33084/bjop.v4i2.1703

\section{INTRODUCTION}

Diabetes (or diabetes mellitus; DM) is a chronic metabolic disease characterized by increased blood glucose levels ${ }^{1}$. These conditions are associated with carbohydrate, fat, and protein metabolism disorders due to insulin and severe conditions of microvascular, macrovascular, and chronic neuropathy ${ }^{2}$. Approximately 476 million people worldwide have DM, mostly in poor and developing countries $^{3}$. The prevalence of DM in Indonesia is $6.2 \%$, and Indonesia is among the ten countries with 10 million living with $\mathrm{DM}^{4}$.
The American Diabetes Association classifies DM into 4;

DM type 1, type 2, gestational DM, and certain types of $\mathrm{DM}$ due to other causes such as monogenic diabetes syndrome, exocrine pancreatic disease, and DM trigger drugs ${ }^{1,5}$. In the last three decades, the prevalence of type 2 diabetes (T2DM) has increased dramatically. Affordability of access to treatment, including insulin, is essential for the survival of people with $\mathrm{DM}^{6,7}$. However, therapy for T2DM uses more antihyperglycemic drugs rather than insulin, such as biguanides, sulfonylureas, meglitinides, thiazolidinedione (TZD), dipeptidyl peptidase 4 (DPP-4) inhibitors, sodium-glucose 
cotransporter inhibitors (SGLT2), and a-glucosidase inhibitors, which is synthetic drugs with various adverse effects $^{8}$.

Diabetes mellitus treatment without adverse effects is still the biggest challenge for medical practitioners. Synthetic drugs used to treat DM are often associated with various disturbing adverse effects such as nausea, vomiting, dysentery, alcohol flush, migraines, swelling, malignant anemia, and fainting, 910 . For this reason, the approach currently being developed by many researchers is to develop natural herbal preparations as DM therapy ${ }^{11}$.

Traditional medicine is carried out from generation to generation because it is believed to be an effective treatment with minimal side effects. However, most of the plants used have not been scientifically tested. The increase in traditional medicines is the reason for the many studies related to the efficacy of secondary metabolites found in plants ${ }^{12,13}$. According to world ethnobotanical, 800 medicinal plants are used for the prevention of T2DM. Clinically proven that only 450 medicinal plants possess anti-diabetic properties, from which 109 medicinal plants have a complete mechanism of action ${ }^{14}$.

One of the medicinal plants interesting to research regarding its properties as an antihyperglycemic is bawang dayak, a typical plant from Central Kalimantan, Indonesia. Bawang dayak or Eleutherine palmifolia is believed to have the efficacy of curing various types of diseases, including $\mathrm{DM}^{15}$. Secondary metabolites of bawang dayak bulbs contain alkaloids, saponins, tannins, phenolics, triterpenoids, steroids, sterols, and flavonoids ${ }^{16,17}$. Bawang dayak bulbs have activity as an inhibitor of a-glucosidase, assisting lower glucose levels in the body ${ }^{18}$. The a-glucosidase inhibitors are one of the antidiabetic agents that work by inhibiting a-glucosidase, in which this enzyme plays a role in the decomposition of polysaccharides into monosaccharides ${ }^{19}$.
Research on the effects of bawang dayak has been widely reported, both related to chemical compound content and various pharmacological activities of bawang dayak, including reducing blood glucose levels. However, previous studies on the effects of bawang dayak only compared the activity between bawang dayak extract and oral diabetes drugs; There has been no research on the effects of bawang dayak extract combined with oral diabetes drugs. One of them is the research results of Febrinda et al. ${ }^{15}$, which showed that $100 \mathrm{mg} / \mathrm{kg}$ of bawang dayak extract could maintain the bodyweight of diabetic rats and significantly reduce blood serum glucose levels. The difference between this study and the previous study was in the treatment, where the test animals were given a combination of bawang dayak extract and the oral diabetes drug: acarbose. The choice of acarbose is based on its mechanism of action, which works as a-glucosidase inhibitors so that it is expected to provide a synergistic effect with bawang dayak extract ${ }^{20}$. The purpose of this study was to compare the hypoglycemic effect between the combination of bawang dayak extract and acarbose with single acarbose.

\section{MATERIALS AND METHODS}

\section{Materials}

The test subject was a white rat, Strain Sprague-Dawley, aged two to three months and weighing 200-250 g. The ingredients used were bawang dayak bulbs, 96\% ethanol, acarbose, and dexamethasone injection. Fresh bawang dayak bulbs (Figure 1) were collected from Palangka Raya, Central Kalimantan, Indonesia. Plant determination was carried out by the Basic Laboratory of the Faculty of Mathematics and Science, Universitas Lambung Mangkurat, and identified as Eleutherine palmifolia (L) Merr. The instruments used were rotary evaporators, water baths, injection syringes, animal scales, glucose strips, and digital glucometers. 


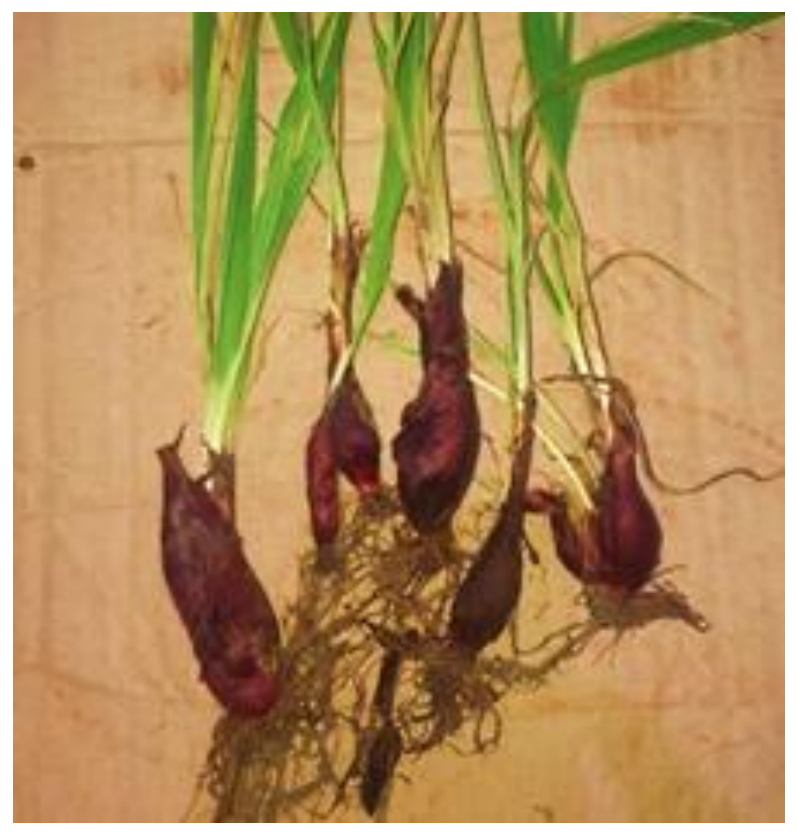

Figure 1. Fresh bawang dayak bulbs

\section{Methods}

Preparation of simplicia powder

Fresh bawang dayak bulbs cleaned of dirt and then washed with running water until clean. The bulbs were then cut and oven-dried at $40^{\circ} \mathrm{C}$. The purpose of producing simplicia into powder was to increase the surface area of the bulbs so that the surface of simplicia in contact with the solvent becomes broader, and more active compounds could be extracted ${ }^{21}$. The resulting powder was then sieved with mesh number 20.

\section{Preparation of ethanol extract}

Bawang dayak powder was put into the maceration chamber and then extracted with $96 \%$ ethanol solvent with a sample : solvent ratio of $1: 1$. The maceration process was carried out for three days with solvent replacement every 24 hours, alternated with stirring every 6 hours. The liquid extract obtained was then collected and concentrated using a rotary evaporator at $40-50^{\circ} \mathrm{C}$. The thick extract obtained was then dried using a water bath at a temperature of $50^{\circ} \mathrm{C}$ until a constant weight was obtained.

\section{Preparation of test animals}

The test animals used were white Sprague-Dawley rats aged two to three months, with a bodyweight of 200-250 g obtained from CV. Mera Medika. The test animals were placed in cages at room temperature with a light/dark cycle every 12 hours and fed with standard animal pellets and free water. This research was conducted following established ethical norms and approved by the Medical Research Ethics Committee of the Faculty of Medicine, Universitas Lambung Mangkurat (No. 407/KEPK-FK UNLAM/EC/IX/2020). All test animals were then fasted for 12 hours before the experiment but were given free access to water.

\section{Blood glucose level reduction test}

All test animals had their blood glucose levels measured to determine their blood glucose levels before treatment. All test animals were then divided into two groups, each consisting of 16 test animals. Each group was then injected with dexamethasone at a $1 \mathrm{mg} / \mathrm{kg}$ BW dose dissolved in $0.9 \% \mathrm{NaCl}_{\text {subcutaneously }}{ }^{22}$. On the $13^{\text {th }}$ day after giving dexamethasone, blood glucose levels were measured using glucose strips and digital glucometers. Each group of test animals was then subjected to an antihyperglycemic test. The dose of bawang dayak extract used in this study was $100 \mathrm{mg} / \mathrm{kg}$ BW and acarbose $40 \mathrm{mg} / 100 \mathrm{~g}$ BW. The first group was treated with a combination of bawang dayak bulbs and acarbose for 15 days, and the second group was treated with acarbose only for 15 days. Fasting blood glucose measurements of test animals were carried out from the tail blood vessels (lateral veins). Data collection was carried out every three days for 15 days after being fulfilled for +10 hours with measurements using glucose strips and digital glucometers.

\section{Data analysis}

For data analysis, the parameter used was a decrease in fasting blood glucose levels. The decrease in fasting blood 
glucose levels in the control and test groups was analyzed by using the General Linear Model test at a $95 \%$ confidence level.

\section{RESULTS AND DISCUSSION}

Extraction was carried out by maceration of $2 \mathrm{~kg}$ of bawang dayak bulbs using $96 \%$ ethanol as a solvent. The dry extract obtained was $46 \mathrm{~g}$, so the yield of the extract obtained was $2.3 \%$. This number is smaller than other studies, as reported by Yuswi ${ }^{23}$ with a yield of $7.58 \%$ and Novaryatiin et al. ${ }^{24}$ with $6.65 \%$. This difference was mainly influenced by the extraction method used, in which the maceration method does give lower yields than reflux or percolation. However, the maceration procedure was relatively easy because it did not require continuous attention ${ }^{21}$.

Figure 2 shows the average blood glucose levels from $D+3$ to $D+15$ in the combination group of bawang dayak and acarbose as well as the single acarbose group. From Figure 2, it can be seen that the average glucose level in the combination group was lower than that in the single acarbose group. The General Linear Model test results obtained a p-value of 0.00 , which means that there is a significant difference in the decrease in blood glucose levels of the test animals.

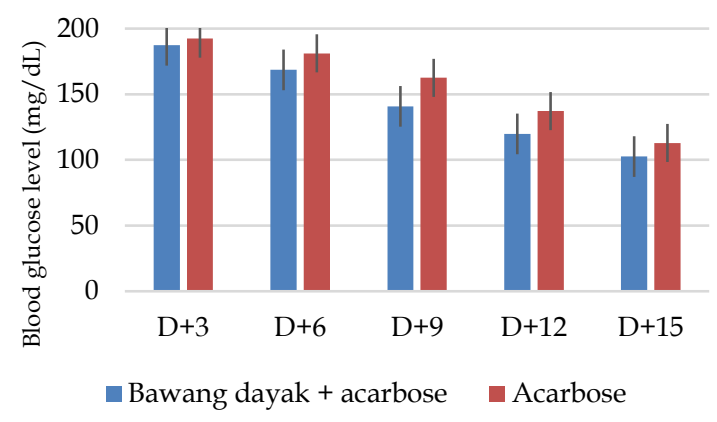

Figure 2. Blood glucose level of each test group during observation

In this study, it was found that after administering subcutaneous dexamethasone to mice for 12 days, there was an increase in blood glucose levels exceeding normal blood glucose levels in mice $(50-135 \mathrm{mg} / \mathrm{dL})^{25}$. Dexamethasone administration would increase blood glucose levels and reduce insulin sensitivity ${ }^{26}$. Studies with rodent models show that glucocorticoids regulate lipid metabolism in skeletal muscle by increasing $\beta$ oxidation and lipolysis ${ }^{27}$. In addition, administration of glucocorticoids also results in inhibition of 11ß-HSD1 expressed in muscle, thereby decreasing lipogenic and lipolytic genes ${ }^{28}$. Therefore, glucocorticoids regulate carbohydrate and lipid metabolism in skeletal muscle, which could play an essential role in regulating muscle insulin sensitivity throughout the body ${ }^{29}$.

The results showed a decrease in blood glucose levels in the test animals in both groups. However, the combination group's decrease in blood glucose levels was lower than the single acarbose group, with the most significant difference occurring on day 9 with 21.69 $\mathrm{mg} / \mathrm{dL}$. After that, the difference between the two groups decreased until the $15^{\text {th }}$ day; the difference was $10.38 \mathrm{mg} / \mathrm{dL}$. These results indicate that the optimal effect of the bawang dayak extract and acarbose combination was shown on the $9^{\text {th }}$ day after administration.

The decrease in blood glucose levels in the combination group of bawang dayak and acarbose on day 12 was within the range of normal blood glucose levels in test animals. The results indicate that the active compounds in bawang dayak provide a synergistic effect with acarbose to reduce blood glucose levels. These results are in line with previous studies that reported that bawang dayak extract showed a significant ability to lower blood glucose levels than untreated test animals; besides can also increase the concentration of insulin ${ }^{15,30,31}$.

Bawang dayak contains several phytochemical compounds such as flavonoids, alkaloids, tannins, and saponins, each of which has an anti-diabetic role. The flavonoid compound group is reported to have anti- 
diabetic activity by regenerating damaged pancreatic $\beta$ cells $^{32}$. Alkaloids and tannins have astringent properties by inhibiting the absorption of sugar on the surface of the small intestine, which in turn can lower blood sugar levels $^{33}$. Whereas saponins can regenerate pancreatic cells, causing an increase in the number of pancreatic $\beta$ cells and islets of Langerhans increases insulin secretion. Increased insulin secretion will help lower blood sugar levels ${ }^{34}$

\section{CONCLUSION}

The combination of bawang dayak extract and acarbose can reduce blood glucose levels to a greater extent than single acarbose.

\section{ACKNOWLEDGMENT}

The author would like to thank the Sekolah Tinggi Ilmu Kesehatan ISFI Banjarmasin, especially the Pharmacology Laboratory, for providing research facilities and infrastructure.

\section{AUTHORS' CONTRIBUTION}

Aditya Maulana Perdana Putra: conceptualization, data curation, investigation, software, writing-original draft. Ratih Pratiwi Sari: formal analysis, methodology, validation, writing-review \& editing. Siska Musiam: project administration, resources, supervision, visualization, writing-review \& editing.

\section{DATA AVAILABILITY}

All data are available from the authors.

\section{CONFLICT OF INTEREST}

There are no conflicts of interest.

\section{REFERENCES}

1. American Diabetes Association. Diagnosis and Classification of Diabetes Mellitus. Diabetes Care. 2014;37(Suppl 1):S81-90. doi:10.2337/dc14-S081

2. Vieira R, Souto SB, Sánchez-López E, Machado AL, Severino P, Jose S, et al. Sugar-Lowering Drugs for Type 2 Diabetes Mellitus and Metabolic SyndromeReview of Classical and New Compounds: Part-I. Pharmaceuticals. 2019;12(4):152. doi:10.3390/ph12040152

3. Lin X, Xu Y, Pan X, Xu J, Ding Y, Sun X, et al. Global, regional, and national burden and trend of diabetes in 195 countries and territories: an analysis from 1990 to 2025. Sci Rep. 2020;10:14790. doi:10.1038/s41598-02071908-9

4. Ligita T, Wicking K, Francis K, Harvey N, Nurjannah I. How people living with diabetes in Indonesia learn about their disease: A grounded theory study. PLoS One. 2019;14(2):e0212019. doi:10.1371/journal.pone.0212019

5. Skyler JS, Bakris GL, Bonifacio E, Darsow T, Eckel RH, Groop L, et al. Differentiation of Diabetes by Pathophysiology, Natural History, and Prognosis. Diabetes. 2017;66(2):241-55. doi:10.2337/db16-0806

6. Marín-Peñalver JJ, Martín-Timón I, SevillanoCollantes C, del Cañizo-Gómez FJ. Update on the treatment of type 2 diabetes mellitus. World J Diabetes. 2016;7(17):354-95. doi:10.4239/wjd.v7.i17.354

7. Sami W, Ansari T, Butt NS, Hamid MRA. Effect of diet on type 2 diabetes mellitus: A review. Int J Health Sci. 2017;11(2):65-71.

8. Chaudhury A, Duvoor C, Dendi VSR, Kraleti S, Chada A, Ravilla $R$, et al. Clinical Review of Antidiabetic Drugs: Implications for Type 2 Diabetes Mellitus Management. Front Endocrinol. 2017;8:6. doi:10.3389/fendo.2017.00006

9. Chaturvedi R, Desai C, Patel P, Shah A, Dikshit RK. An evaluation of the impact of antidiabetic medication on treatment satisfaction and quality of life in patients of diabetes mellitus. Perspect Clin Res. 2018;9(1):15-22. doi:10.4103/picr.PICR_140_16

10. May M, Schindler C. Clinically and pharmacologically relevant interactions of antidiabetic drugs. Ther Adv Endocrinol Metab. 2016;7(2):69-83. doi:10.1177/2042018816638050 
11. Choudhury H, Pandey M, Hua CK, Mun CS, Jing JK, Kong L, etal. An update on natural compounds in the remedy of diabetes mellitus: A systematic review. J Tradit Complement Med. 2018;8(3):361-76. doi:10.1016/j.jtcme.2017.08.012

12. Seca AML, Pinto DCGA. Biological Potential and Medical Use of Secondary Metabolites. Medicines. 2019;6(2):66. doi:10.3390/medicines6020066

13. Sofowora A, Ogunbodede E, Onayade A. The Role and Place of Medicinal Plants in the Strategies for Disease Prevention. Afr J Tradit Complement Altern Med. 2013;10(5):210-29. doi:10.4314/ajtcam.v10i5.2

14. Salehi B, Ata A, Kumar NVA, Sharopov F, RamírezAlarcón K, Ruiz-Ortega A, et al. Antidiabetic Potential of Medicinal Plants and Their Active Components. Biomolecules. 2019;9(10):551. doi:10.3390/biom9100551

15. Febrinda AE, Yuliana ND, Ridwan E, Wresdiyati T, Astawan M. Hyperglycemic control and diabetes complication preventive activities of bawang dayak (Eleutherine palmifolia L. Merr.) bulbs extracts in alloxan-diabetic rats. Int J Food Res. 2014;21(4):140511.

16. Wardani IGAAK, Megawati F, Suena NMDS. The Effect of Dayak Onion Bulb Ethanol Extract (Sisyrinchium palmifolium L.) on Triglyceride Level and Aorta Histopathology in Diabetes Melitus White Rat Induced by Alloxan. Majalah Obat Tradisional. 2019;24(2):77-84. doi:10.22146/mot.38051

17. Novaryatiin S, Ardhany SD. The antibacterial activity of bawang dayak (Eleutherine bulbosa (Mill.) Urb.) from central kalimantan against acne-causing bacteria. Int J Appl Pharm. 2019;11(5):22-5. doi:10.22159/ijap.2019.v11s5.T0032

18. Febrinda AE, Astawan M, Wresdiyati T, Yuliana ND. Kapasitas Antioksidan Dan Inhibitor Alfa Glukosidase Ekstrak Umbi Bawang Dayak [Antioxidant and Alpha-Glucosidase Inhibitory Properties of Bawang Dayak Bulb Extracts]. Jurnal Teknologi dan Industri Pangan. 2013;24(2):161-7. doi:10.6066/jtip.2013.24.2.161

19. Proenca C, Freitas M, Ribeiro D, Oliveira EFT, Sousa JLC, Tomé SM, et al. a-Glucosidase inhibition by flavonoids: an in vitro and in silico structure-activity relationship study. J Enzyme Inhib Med Chem. 2017;32(1):1216-28. doi:10.1080/14756366.2017.1368503
20. Yang HK, LeeSH, Shin J, Choi YH, Ahn YB, Lee BW, etal. Acarbose Add-on Therapy in Patients with Type 2 Diabetes Mellitus with Metformin and Sitagliptin Failure: A Multicenter, Randomized, Double-Blind, Placebo-Controlled Study. Diabetes Metab J. 2019;43(3):287-301. doi:10.4093/dmj.2018.0054

21. Zhang QW, Lin LG, Ye WC. Techniques for extraction and isolation of natural products: a comprehensive review. Chin Med. 2018;13:20. doi:10.1186/s13020-018-0177-x

22. Martínez BB, Pereira ACC, Muzetti JH, Telles FdP, Mundim FGL, Teixeira MA. Experimental model of glucocorticoid-induced insulin resistance. Acta Cir Bras. 2016;31(10):645-9. doi:10.1590/s0102865020160100000001

23. Yuswi NCR. Ekstraksi Antioksidan Bawang Dayak (Eleutherine palmifolia) Dengan Metode Ultrasonic Bath (Kajian Jenis Pelarut Dan Lama Ekstraksi). Jurnal Pangan dan Agroindustri. 2017;5(1):71-9.

24. Novaryatiin S, Ramli A, Ardhany SD. Uji Daya Hambat Ekstrak Etanol Bawang Dayak (Eleutherine bulbosa (Mill.) Urb.) terhadap BakteriStaphylococcus aureus. Jurnal Surya Medika (JSM). 2019;4(2):51-9. doi:10.33084/jsm.v4i2.565

25. King AJF. The use of animal models in diabetes research. Br J Pharmacol. 2012;166(3):877-94. doi:10.1111/j.1476-5381.2012.01911.x

26. Suh S, Park MK. Glucocorticoid-Induced Diabetes Mellitus: An Important but Overlooked Problem. Endocrinol Metab. 2017;32(2):180-9. doi:10.3803/EnM.2017.32.2.180

27. Morgan SA, Gathercole LL, Simonet C, HassanSmith ZK, Bujalska I, GuestP, etal. Regulation of lipid metabolism by glucocorticoids and 11 $\beta$-HSD1 in skeletal muscle. Endocrinology. 2013;154(7):2374-84. doi:10.1210/en.2012-2214

28. Morgan SA, Sherlock M, Gathercole LL, Lavery GG, Lenaghan C, Bujalska IJ, et al. 11/-Hydroxysteroid Dehydrogenase Type 1 Regulates GlucocorticoidInduced Insulin Resistance in Skeletal Muscle. Diabetes. 2009;58(11):2506-15. doi:10.2337/db09-0525

29. Kuo T, McQueen A, Chen TC, Wang JC. Regulation of Glucose Homeostasis by Glucocorticoids. Adv Exp Med Biol. 2015;872:99-126. doi:10.1007/978-1-49392895-8_5 
30. Arwati N, Wirjatmadi B, Adriani M, Meilanani S, Winarni $D$, Hartiningsih $S$. The effect of dayak onion bulb-stem (Eleutherine palmifolia (1.)) Merr.) extract on blood glucose levels of mouse suffered diabetes mellitus. Health Notions. 2018;2(3):368-72.

31. Yaturramadhan H, Dalimunthe A, Widyawati T. The Effect of Ethanolic Extract of Dayak Onion (Eleutherine palmifolia (L) Merr) Tuber on Blood Glucose and Insulin Level of Streptozotocin-Induced Diabetic Wistar Rat. Asian J Pharm Res Dev. 2019;7(4):38-42. doi:10.22270/ajprd.v7i4.548

32. Al-Ishaq RK, Abotaleb M, Kubatka P, Kajo K, Büsselberg D. Flavonoids and Their Anti-Diabetic Effects: Cellular Mechanisms and Effects to Improve Blood Sugar Levels. Biomolecules. 2019;9(9):430. doi:10.3390/biom9090430

33. Zulcafli AS, Lim C, Ling AP, Chye S, Koh R. Antidiabetic Potential of Syzygium sp.: An Overview. Yale J Biol Med. 2020;93(2):307-25.

34. Oh YS. Plant-Derived Compounds Targeting Pancreatic Beta Cells for the Treatment of Diabetes. Evid Based Complement Alternat Med. 2015;2015:629863. doi:10.1155/2015/629863 